\title{
Waqf Development in Marawi City via Issuance of Perpetual Waqf Sukuk
}

Nur Diyanah Syakirah Mohd Shukri ${ }^{1}$

Siti Nuralina Ahmad Zamri ${ }^{1}$

Aishath Muneeza ${ }^{1}$

Hanif Ghulam ${ }^{2}$

\author{
${ }^{1}$ International Centre for Education in Islamic Finance (INCEIF) \\ ${ }^{2} \mathrm{CIMB}$, Malaysia
}

\begin{abstract}
Since 2017, the city of Marawi was left in ruins after five months of aerial bombardments and close-quarter fighting between Islamic State of Iraq and al-Sham (ISIS) and government forces. Many buildings were destroyed; mosques and schools are no exceptions. While rebuilding efforts have begun in the city, the government has limited resources to fund city reconstruction and Waqf properties (e.g. mosques and schools) are not constitutionally considered as part of the government assets. Fortunately, the government seeks to channel funding for city reconstruction, including Islamic finance schemes. Therefore, this paper aims to assess the opportunities and challenges to rebuild Waqf properties through the issuance of Sukuk, Islamic bond. This paper adopts a qualitative research approach where secondary sources such as books, journals, articles and websites related to Waqf are reviewed. The paper also examines the successful examples of Sukuk-Waqf as part of the analysis.
\end{abstract}

Keywords: Marawi City; Philippines; Perpetual Sukuk; Waqf; Waqf Sukuk; Islamic Finance; City Reconstruction 


\section{Introduction}

Marawi city, situated on the southern island of Mindanao in the Philippines has been known as a spiritual and cultural centre of the Muslims in that state. It is considered as the largest Muslim city in a predominantly Catholic nation (Gamon and Tagoranao, 2017). Marawi city has been known as the only "Islamic city" of the Philippines for having many beautiful masajid (mosques) and madaris (schools) in every district of the city (Gamon and Tagoranao, 2017). Most of the masajid and madaris were built on the Waqf lands and financed by cash Waqf contributed by individuals and religious private organizations (Gamon and Tagoranao, 2018). Other than educational and religious establishments, there are also Waqf properties dedicated for community services such as health services, water system, shelter and others (Gamon and Tagoranao, 2017). Unfortunately, most of them were destroyed due to an urban siege between Islamic State of Iraq and al-Sham (ISIS) fighters and government forces which happened on May 23, 2017, and ended five months later on October 23, 2017 (Gamon and Tagoranao, 2017).

According to Asian Development Bank (2018), total damages reached USD 348 million, 22 schools were seriously destroyed and 5,627 dwellings were completely damaged. The Waqf lands used for the masjid (mosque), madrasah (school), water system, dormitories, and other charitable properties were mostly part of ancestral lands converted to Waqf properties as agreed upon or with the consent of the members of the respective family (Gamon and Tagoranao, 2017). These Waqf properties gave something that the government of the Philippines failed to provide to the Muslim minority. According to Gamon (2001), Waqf has become the only financial source for Muslims scholars to produce research output that contributes to the development of the Muslim culture and activities in the Philippines.

Islamic bond (Sukuk) has been considered as part of Philippine President Rodrigo Duterte's "Build, Build, Build" programme to fund infrastructure projects (Maierbrugger, 2019). According to Romeo Montenegro, the director of Mindanao Development Authority (MinDA), Islamic finance recovery scheme for Marawi is viable if a general framework for Islamic finance ecosystem is in place (Maierbrugger, 2017). The development of Islamic finance industry in the Philippines is still at its early stages as there is only one Islamic bank in the country -- Al Amanah Islamic Investment Bank of the Philippines, which does not operate as a full-fledged Islamic bank.

Waqf institutions are significant to Muslims communities. There are successful cases of Sukuk issuance as a way to fund Waqf development. Hence, this paper intends to redevelop Marawi Waqf institution through the issuance of perpetual Sukuk. This paper aims to identify potential risks involved in issuing perpetual Sukuk to fund Waqf institutions.

International Journal of Management and Applied Research, 2019, Vol. 6, No. 2 


\section{Waqf Development}

The word 'Waqf' (plural Awqaf) derives from the Arabic language that literally means to withhold. According to Imam Abu Hanifah, "Waqf is withholding a subject matter (asset) to be under the exclusive ownership of the endower (Waqif) and to give in charity its usufruct or dispose of its usufruct to a party chosen by the endower" (cited by Islam, 2018, p. 1132). The term Waqf in English can be translated as a religious endowment to withhold or preserve certain philanthropic charity and to prohibit any use or disposition of the property outside the property specific purposes (Mohsin and Muneeza, 2019). Sadeq (2002, p. 139) defines Waqf as "the locking up of the title of an owned asset from disposition and allotment of its benefits for a specific purpose or purposes". The religious endowment involves the permanent dedication of property to charitable purposes such as financing or creating hospitals, orphanage, and religious establishments like mosques and Islamic school. Moreover, as Waqf belongs to Allah SWT, it should never be gifted, inherited or sold (Gamon and Tagoranao, 2018; Khan and Jareen, 2015; Sadeq, 2002).

In the history of the Muslim world, Waqf institutions have long been recognized by its vital role in economic growth and regional development. During the Ottoman Empire era in the $16^{\text {th }}$ century, cash Waqf was widely used to finance the entrepreneurs in their businesses. In turn, the financial gains from their businesses were used for public infrastructure such as roads, bridges, and others. However, the utilization of Waqf has begun to decline at the end of the $19^{\text {th }}$ century because of mismanagement, colonization, and secularism (Mohsin and Muneeza, 2019). Similarly, contemporary Waqf institution has declined in effectiveness throughout the Muslim world due to financial and managerial constraints (Allah Pitchay et al., 2018). For instances, Bencoolen Mosque in Singapore, known as the oldest Waqf property in the country was having financial constraints which enforced one of its trustees, Rajab Ally bin Kasim Jeammedah to make a petition for the sustainable fund to ensure the retention of that Waqf property (Nagaoka, 2016). This Bencoolen Waqf case study will be explained further in later section.

\subsection{Waqf land and properties in Marawi city}

There are several madaris institutions and masajid in Marawi city. For example, Jamiatul Philippine al-Islamiyyah (JPI) was built by a prominent family under family Waqf, Maahad Marawi Al-Islami funded by Kingdom of Saudi Arabia, Islamic Development Bank; others such as Madrasah Waqf Qismul Banaat and Masjid Islamic Centre were located in the centre of Marawi City. Unfortunately, after the war, these long established madaris and masajid were destroyed completely because of the urban siege (Gamon and Tagoranao. 2017).

In the past, there were no specific laws that govern Waqf matters due to political and religious reasons, and government interfered minimally after the independence. Code of Muslim Personal Laws of the Philippines, which took effect on 4 February 1977, applies to all Muslims in the country. The administration of ancestral lands and charitable trust property as part of the communal property is expressly provided in the Muslim Code (Gamon and Tagoranao. 2018). The government provides exemption on

International Journal of Management and Applied Research, 2019, Vol. 6, No. 2 
real property tax on all lands, buildings, and improvements according to Section 28(3) of Article VI of the Philippine Constitutions (Gamon and Tagoranao, 2017).

\subsection{Challenges of Utilising Waqf}

There are significant constraints that may hinder Waqf development. One of the greatest challenges in structuring and managing Waqf assets is the low awareness of the need to pay Waqf. Such limited Waqf awareness can be attributed to the ineffective communication channels to attract donors (Allah Pitchay et al., 2018) and poor governance (Khan and Jareen, 2015). In Malaysia, for instance, most of the Waqf lands remain underdeveloped despite government funding (Allah Pitchay et al., 2018).

Characterised by perpetuity, the ownership of Waqf properties cannot be transferred, sold, or changed (Khan and Jareen, 2015). In the past, Waqf lands were better protected against division among heirs and confiscation by rulers (Islam, 2018); however, the perpetual characteristic of Waqf implies that the administration of Waqf land and property lack the flexibility necessary for efficient resource utilisation.

Apart from the prohibition of ownership transfer, Waqf lands and properties cannot be used as collateral due to its perpetuity characteristic (Gamon and Tagoranao, 2018). The usage of a Waqf asset or property is limited to its usufruct rights (Khan and Jareen, 2015), and thus financiers and management need to be more innovative in developing Waqf properties.

\section{Perpetual Sukuk}

Accounting and Auditing Organization for Islamic Financial Institutions (AAOIFI) defines Sukuk as the "certificates of equal value that representing undivided shares in ownership of tangible assets, usufructs and services, or (in the ownership of) the assets particular projects or special investment activities" (AAOIFI, 2008, p. 307). The Sukuk market has developed a variety of structures, with the latest innovative instruments such as convertible and perpetual Sukuk. Perpetual Sukuk is an additional feature of normal Sukuk. According to International Shariah Research Academy for Islamic Finance (ISRA) (2017), a Sukuk is entitled as perpetual if there is no maturity date for redemption while Sukuk holders continue to receive a profit rate until they choose to cash it in. Sukuk issuer can halt periodic distributions to investors at its discretion (Collins et al., 2013). The conditionality of payments means that perpetual Sukuk behaves more like equity than debt (Reuters, 2012).

Perpetual Sukuk is categorized as one of the hybrid instruments in modern financial terms. It is considered as a hybrid because of the incorporation of two elements: debt and equity. Perpetual Sukuk has the characteristic of loss absorption and equity-like features of permanence which are similar to the perpetual bond (ISRA, 2017).

In response to the financial crisis in 2007-8, members of the Basel Committee on Banking Supervision introduced Basel III, a new set of international banking

International Journal of Management and Applied Research, 2019, Vol. 6, No. 2 
regulations to strengthen prudential control. The regulatory capital of a bank is divided into Tier 1 and Tier 2; the distinction is important because security instruments included in Tier 1 capital have the highest level of subordination and must be comprised of highly liquid assets. Tier 1 is subdivided into two: Common Equity Tier 1 and Additional Tier 1. Basel III increased the requirement of minimum Tier 1 capital from $4 \%$ under Basel II to $6 \%$. Additionally, Basel III allows $1.5 \%$ of Tier 1 capital to be in the form of Additional Tier 1 capital, a layer of additional capital capable of absorbing losses (MIFC, 2013). To be qualify as Additional Tier 1, an instrument must be subordinated to depositors, has no maturity date, the issuer has the full discretion to cancel periodic distributions to investors, and such payment cancellation must not impose any restrictions on the issuer (Collins et al., 2013).

By its very nature, perpetual Sukuk qualified as this type of capital because it has no maturity date and it has the features of subordination of holders and the conditionality of payments. The discretion to cancel distributions and capability of absorbing losses increase the resilience of a financial institution (Collins et al., 2013). Perpetual Sukuk also presents a cost-effective means of widening investor base without diluting shareholders, which helps to preserve ownership structure (MIFC, 2013). It is attractive to global investors since it not only allows them to diversify their risk portfolio but also receive higher yields than term deposits or conventional debt instruments (Collins et al., 2013).

To meet the tighten capital requirement set by Basel III, Islamic Financial Institutions (IFIs) innovate a new breed of Basel III compliant Sukuk. The first issuance of Basel III compliant Sukuk came from Abu Dhabi Islamic Bank (ADIB) which sold USD 1 Billion through perpetual Sukuk, attracted a spectacular order book of over USD 15 billion in 2012 (Lahsasna et al., 2018). As shown in the case of ADIB, perpetual Sukuk can generate huge interest and demand among global investors. This can provide finance seekers with additional funding options and allow investor to participate in a wider range of investment opportunities amid a changing regulatory environment.

\section{Successful Projects of Rebuild Waqf Properties by Utilizing Sukuk}

There are two Sukuk that was issued to develop the Waqf properties: Sukuk al-Intifa' and Sukuk al-Musharakah. These two Sukuk issuances successfully financed the construction of immovable Waqf properties and more importantly, the Sukuk issuance generates further income. Prior to the discussion of the scope of perpetual Sukuk in the development of Waqf properties in Marawi city, it is important to examine the successful cases of using Sukuk to develop Waqf properties. Sukuk al-Intifa' and Sukuk al-Musharakah are considered as exemplary due to the special features of underlying Shariah contracts. These two cases combine the use of both leases and bonds, and fully demonstrate how asset-backed financing could contribute to economic growth and regional development. This part of the paper discusses these two financial structures.

International Journal of Management and Applied Research, 2019, Vol. 6, No. 2 


\subsection{Sukuk al-Intifa'}

Sukuk al-Intifa' is a certificate of ownership of usufructs through leasing asset or property over certain period of time (Rafay et al., 2017). It is also recognized as time sharing bond between two parties: Sukuk issuer and holder. Based on the concept of Ijarah (lease), the Sukuk holder pays the rent in the form of bond. In this way, Sukuk issuer can raise funding from a variety of interested investors while Sukuk holder can be benefitted from the use of the property and gained through the time utility.

One exemplar of the issuance of Sukuk al-Intifa' is the Zamzam Tower project in Mecca. More specifically, Sukuk al Intifa was issued in 2004 for the purpose of developing the King Abdul Aziz Waqf's land which is adjacent to the grand mosque in Mecca, Saudi Arabia. The waqf land was leased by King Abdul Aziz Endowment to build four towers, a shopping complex, and a hotel under the Zamzam Tower project. The building of Zamzam Tower belongs to the developer; usufruct belongs to Sukuk holders and the Waqf land owned by King Abdul Aziz Endowment (Waqf). Figure 1 shows the structure of Sukuk-Waqf to finance Zamzam Tower project in Mecca.

Figure 1: Sukuk al-Intifa' structure in Zamzam Tower project

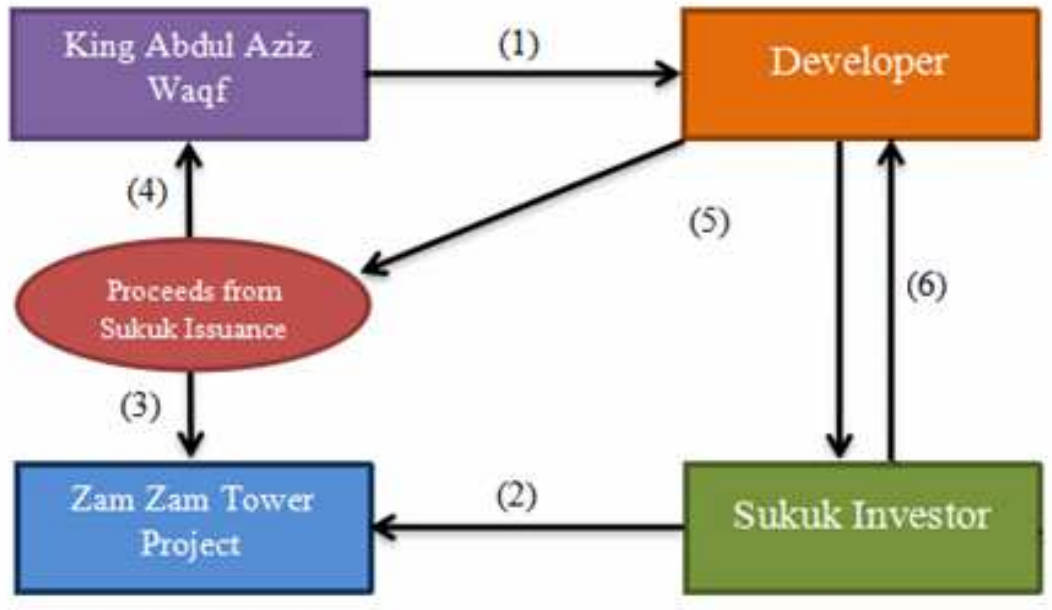

1. Ijarah contract on use of land

2. Time Use by Sukuk holders

3. Development costs

4. Payment for the lease of land

5. Issuance of Sukuk al-Intifa' and Lease of Rights of Future Use of Units On Chosen Time Slots

6. Payment for lease rental (forward leasing)

The Zamzam Tower project was allotted to Bin-Ladin Group of Companies, which in turn, leased the project to Manshaat Real Estates for 24 years (Lahsasna et al., 2018). Munshaat Real Estate Projects issued US\$390 worth of Sukuk-Waqf as fractional of ownership right onto the project by dividing its usufruct rights into weekly time shares to investors (Rafay et al., 2017). The Sukuk holders own the lease of an apartment for

International Journal of Management and Applied Research, 2019, Vol. 6, No. 2 
a period of one to two weeks. Foreign ownership is forbidden in Mecca and Medina; however, Sukuk holders can sub-let the units on time-sharing basis (Lahsasna et al., 2018). Once the lease period is ended, Bin-Ladin Group of Companies will transfer the project to the King Abdul Aziz Waqf.

\subsection{Sukuk al-Musharakah}

In 2006, Majlis Ugama Islam Singapore (MUIS) issued Sukuk al-Musharakah for the purpose of Waqf renewal by building a mixed development in Bencoolen Street and redeveloping an old mosque in disrepair condition. The funding of the project is structured as follows: firstly, MUIS issues Sukuk and collects SGD 35 million; next, MUIS, Waqf Fund, and Warees (a subsidiary of MUIS) entered a joint venture under a Musharakah framework and built a new estate which consists of a new 12-story service apartment, office units and commercial shop units (Nagaoka, 2016). The completed project is owned by MUIS and managed by Warees. Figure 2 shows the structure of the Sukuk al-Musharakah issued by MUIS in Singapore. While MUIS contributed SGD 35 million as capital, the Waqf Fund provided SGD 4.2m worth land and equity sum of SGD519, 000 (Nagaoka, 2016). Since the Sukuk is backed by assets, it was tradable on the secondary market (Brown, 2008).

Figure 2 Bencoolen project using Sukuk al-Musharakah

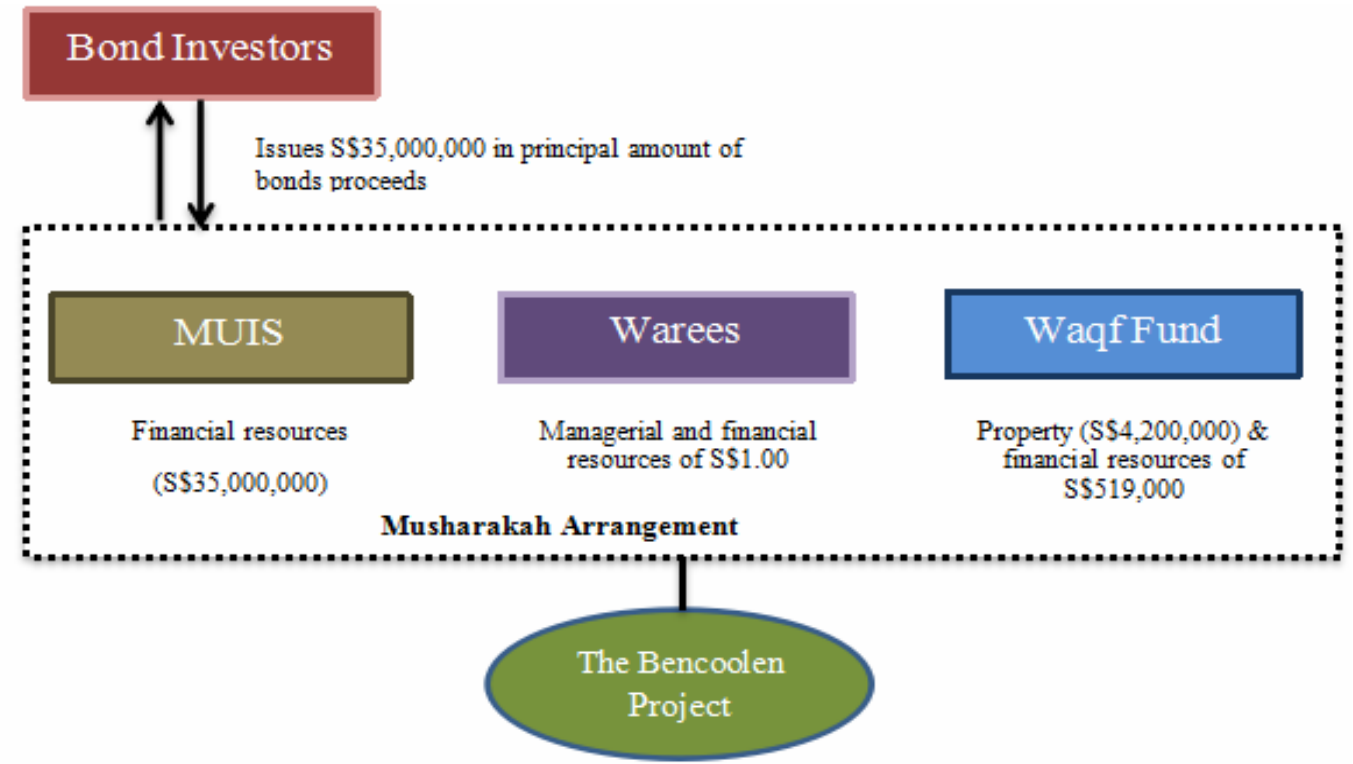

Adapted from: Nagaoka, (2016, p. 10)

As a for-profit distribution, the principal of traditional Musharakah contract, the involved parties must divide profit accordingly in terms of proportion based on the capital parties invested. In other words, the investors receive payment based on agreed rental income. Besides established Warees as a subsidiary, MUIS also created a waqf Treasury (Baitul-Mal) as a separate financial division to manage funds. The independency and fund separation are needed in order to divide capital raised from outside and revenues accumulated through activities within the Waqf (Brown, 2008).

International Journal of Management and Applied Research, 2019, Vol. 6, No. 2 
There are two arrangements involved in the Bencoolen project: first, a joint venture partnership (Musharakah); and second, a leasing (Ijarah) arrangement coordinated between MUIS and a property maintenance company, Ascott International. The rent received from the Ijarah agreement provides periodic payment on Sukuk. The Ijarah agreement was set for 10 years, with a minimum guaranteed income of SGD1.3m for the first year and SGD1.8m for the remaining years (Abdul-Karim, 2010).

As a result, MUIS improves managerial efficiency of the Waqf property through the combination of joint venture and lease agreement. Besides redeveloped a mosque, the joint venture built shops and apartments, which then lease back for residential and commercial purposes based on Ijarah contract.

\section{Revitalize Waqf Land in Marawi City}

Marawi city faced a huge crisis due to an urban siege in 2017 which caused massive destroy economically and socio-culturally. The Mindanao Development Authority (MinDA) in the Philippines intents to use Islamic financing scheme to fund city reconstruction (Maierbrugger, 2017). Moreover, the Philippines president is keen to diversify the country's investor base by adding Islamic bond to the administration's financing strategy in addition to the existing Panda bond and Samurai bond (Department of Budget and Management, 2018).

Thus, it is believed that a perpetual Sukuk structure might help to redevelop Waqf properties in Marawi City. The proposed finance structure could also fund city reconstruction, a crucial driver of economic growth and job creation.

The proposed perpetual Sukuk to develop Waqf properties will involve mainly three parties and they are the owner of Waqf properties, Special Vehicle Purpose (SPV) and Sukuk holders. In this proposed structure, SPV will be created by the Waqf property owner which could be the local authority or administrator of Waqf properties such as International Al-Waqf Foundation and Markaz al-Shabbāb al-Muslim fil-Filibin (Gamon and Tagoranao, 2018). The purpose to appoint a SPV is to isolate management operations from the Waqf owners (Brown, 2008). The Waqf properties will be transferred to the SPV to manage them as per the trust deed entered between Sukuk issuer (SPV) and the Sukuk holders. In this case, the issuer also acts as the asset trustee who holds the Trust Assets, who has no liberty to sell the Waqf assets. It is also possible for an independent trustee to be appointed by the Sukuk holders to ensure that the SPV fulfils its obligation.

Due to the complexity of city reconstruction, Waqf Sukuk holders may not receive financial returns on time. Accordingly, through this agreement, Waqf Sukuk holders should not be motivated by monetary gains. Instead, by entering Waqf-perpetual Sukuk, they should aim to receive blessing from Allah through funding Waqf properties continuously, the key distinctive feature in this Sukuk. The potential of Waqf Sukuk has been proved by the Indonesian government which launched Waqf-

International Journal of Management and Applied Research, 2019, Vol. 6, No. 2 
linked Sukuk to finance home construction that affected by disaster or public infrastructure projects. The Deputy Governor from Bank Indonesia, Dody Budi Waluyo stated nearly 25 billion rupiahs ( $\$ 1.64$ million) of cash Waqf had been collected for the Sukuk (Suroyo, 2018) and retain financial yield to manage the Waqf asset in the future. Another case which is quite similar in term of purpose is Ihsan Waqf Investment Fund (IWIF) which applies the model of Temporary Cash Waqf to deliver sustainable social outcomes and philanthropic objectives over the long run (Islamic Development Bank, 2018).

Islamic banks may leverage on the technological innovation such as blockchain technology in structuring Islamic finance agreements. It is possible to apply blockchain technology into perpetual Waqf Sukuk by using a smart contract for transaction verification and storage purposes (Mohsin and Muneeza, 2019). A blockchain-based smart contract enables regulators to keep track of all changes in the agreement made between contracting parties (Niforos et al., 2017). Blockchain technology also helps to eliminate administrative burdens such as clearing and settlements, thereby improving operational efficiency (Muneeza et al., 2018).

\section{Challenges to Reconstructing Waqf Properties in Marawi City}

Islamic financial institutions aim at addressing the reconstruction need by creating a Shariah-compliant recovery scheme, the development of which poses challenges arising from political unrest in addition to regulatory complexities. Marketing Waqf Sukuk is another challenge in light of competing with well-developed conventional banking industry. Majority of the Muslim Filipinos do not understand the importance of Waqf (Gamon and Tagoranao, 2017), probably due to the lack of reciprocal communication between Waqf donors and Waqf institutions (Allah Pitchay et al., 2018).

Although city reconstruction has begun in Marawi, the progress of rebuilding is slow. According to Asian Development Bank (2018), damages were estimated at USD 216 million and losses at USD132 million. The reconstruction will be complex and challenging since major parts of the city, including its public infrastructure, have been destroyed after months of combats. The government will have to support Marawi with massive fiscal transfers for years before it will be able to stand again on its feet (Ahmed, 2017). To date, the government has mobilised funding from international donation and national reserves to build infrastructures, but the Philippines President made it clear that he will not help to rebuild private housing (Regencia, 2019), let alone waqf properties. It is unclear whether the Waqf properties will be included in the proposed transformation plan as religious properties are not constitutionally considered as part of the government assets (Gamon and Tagoranao, 2017).

In November 2018, Benjamin Diokno, the secretary of Department of Budget and Management (DBM) of the Republic of the Philippines discussed the opportunities for the development of Islamic finance in the country (DBM, 2018). However, the proposed Islamic finance recovery scheme for Marawi city is not without constraints,

International Journal of Management and Applied Research, 2019, Vol. 6, No. 2 
especially from the legal aspect. The Philippines has its legislative charter. At present, there is no room in creating new funding vehicles within the existing regulation due to the absence of a long-awaited general framework Islamic banking, capital markets and insurance in the country. This non-existence of banking Islamic framework leads extending and/or adopting terms and conditions of existing laws applicable to conventional banking that fit for Islamic recovery financing. All of these would need approval by the central bank of Philippine. Hence, the design of an Islamic recovery fund for Marawi city would be a lengthy and complex process.

Economic growth and political stability are key factors to be considered by investors when making the financial investment. In the cases of Zam Zam Tower and Bencoolen Street, investors react to the issuance of Sukuk positively probably due to the favourable future prospect. Arguably, however, this may not be the case for Waqf properties in Marawi city due to political uncertainty. Although the urban siege was ended after five months, the risk of terror attack is not completely eliminated. The extremist ISIS-affiliated groups have voiced their firm opposition to the peace by continue engaging in violence (Hart, 2018).

\section{Recommendation and Conclusion}

Rebuilding Marawi city could serve as a pilot project for adopting an operational foundation of Islamic finance in the Philippines (Maierbrugger, 2017). As a result of an appeal of Muslim region of Mindanao to use an Islamic finance-back scheme to raise funds for Marawi City's recovery, the Mindanao Development Authority is taking Islamic financial instruments into consideration as a source of funding the reconstruction of the city. Although the size of Islamic rebuild funding is not comprehensible yet, it is likely the local government will arrange Islamic finance schemes along with emergency loan programme through the country's social security system (Maierbrugger, 2017).

Rebuilding war-torn city like Marawi requires steady, reliable, long-term funding, which could come from many different sources such as donation or perhaps taxation (e.g. zakat). In other words, it requires diversified sources of funding which could allow the residents to rebuild their community in the long run. Marawi City is an Islamic city in Philippine. Rebuilding Waqf properties is important to the Muslims communities because it is part of the local culture and spiritual foundation. The proposed Sukuk structure is one of the many ways to rebuild Marawi. A standard manual should be prepared as a part of managing Waqf properties. The Department of Wakaf, Zakat and Hajj in Malaysia has issued a Manual Pengurusan Tanah Wakaf (Manual for Management of Waqf Land), which has a set of guidelines regarding administrations of Waqf such as procedures for payment of Waqf duty, leasing, insurance, and registration of Waqf land. The administrators of Waqf in the Philippines could make good use of it.

The application of perpetual Sukuk to Waqf is in the inception stage, just as the development of an Islamic finance industry is still in its early stages in the

International Journal of Management and Applied Research, 2019, Vol. 6, No. 2 
Philippines. The proposed finance structure described in this paper is an attempt to explore the use of Islamic financial instruments within a framework that must acknowledge the national context, especially the economic, cultural, and legal concerns of potential investors and local residents. Education and marketing activities are recommended to increase the awareness of Waqf. Communication channels such as social media, marketing campaigns, conference proceedings could be used as a medium to promote Waqf.

\section{References}

1. Abdul-Karim, S. (2010), "Contemporary Shari'ah Compliance Structuring for the Development and Management of Waqf Assets in Singapore", Kyoto Bulletin of Islamic Area Studies, Vol. 3, No.2, pp. 143-164.

2. Accounting and Auditing Organization for Islamic Financial Institutions (AAOIFI) (2008), Financial Accounting Standards, Accounting and Auditing Organization for Islamic Financial Institutions, Bahrain, AAOFII.

3. Ahmed, Y. (2017), "After ISIS, what's next for Marawi? How to avoid more violence in the Philippines", Majalla [Online] available from: https://eng.majalla.com/2017/11/article55254889/after-isis-whats-next-for-marawi [Accessed on 20 July 2019].

4. Allah Pitchay, A.; Mohd Thas Thaker, M.; Mydin, A.; Azhar, Z. and Abdul Latiff, A. (2018), "Cooperative-waqf model: a proposal to develop idle waqf lands in Malaysia”, ISRA International Journal of Islamic Finance, Vol. 10 No. 2, pp. 225236. https://doi.org/10.1108/IJIF-07-2017-0012

5. Asian Development Bank (2018), Emergency Assistance for Reconstruction and Recovery of Marawi: Report and Recommendation of the President, [Online] available from: https://www.adb.org/sites/default/files/projectdocuments/52313/52313-001-rrp-en.pdf [Accessed on 20 July 2019].

6. Brown, R. A. (2008), "Islamic Endowments and the Land Economy in Singapore: The Genesis of an Ethical Capitalism, 1830-2007", South East Asia Research, Vol. 16, No. 3, pp. 343-403. https://doi.org/10.5367/000000008787133445

7. Collins, N.; Irvine, L. and Gaskin, R. L. (2013), “Abu Dhabi Islamic Bank leads the way with the world's first Basel III compliant Tier 1 Sukuk issuance", Islamic Finance News, [Online] available from: https://www.lw.com/thoughtLeadership/abu-dhabi-islamic-bank-leads-way [Accessed on 20 July 2019].

8. Cizakca, M. (2000), A history of philanthropic foundations: The Islamic world from the seventh century to the present, Turkey: Boğaziçi University Press

9. Department of Budget and Management (DBM) (2018), DBM Secretary Diokno discusses opportunities for Islamic Finance in ASEAN Universities forum, [Online] available from: https://www.dbm.gov.ph/index.php/secretary-scorner/press-releases/list-of-press-releases/1277-dbm-secretary-diokno-discussesopportunities-for-islamic-finance-in-asean-universities-forum [Accessed on 20 July 2019].

International Journal of Management and Applied Research, 2019, Vol. 6, No. 2 
10. Gamon, A. and Tagoranao, M. (2017), "The Post-War Reconstruction of Waqf Properties in Marawi City: Prospect and Challenges", in: Contemporary Issues on Zakat, Waqf and Islamic Philanthropy, Kuala Lumpur: Academy of Contemporary Islamic Studies. (ACIS), pp. 348-357.

11. Gamon, A. and Tagoranao, M. (2018), "Zakat and Poverty Alleviation in a Secular State: The Case of Muslim Minorities in the Philippines", Studia Islamika, Vol. 25, No. 1, pp. 97-133. https://doi.org/10.15408/sdi.v25i3.5969

12. Hart, M. (2018), "A year after Marawi, what's left of ISIS in the Philippines?", The Diplomat, [Online] available from: https://thediplomat.com/2018/10/a-yearafter-marawi-whats-left-of-isis-in-the-philippines/ [Accessed on 20 July 2019].

13. International Shariah Research Academy for Islamic Finance (ISRA) (2017) Sukuk: Principles \& Practices. Kuala Lumpur: ISRA.

14. Islam, M. T. (2018), "Historical Development of Waqf Governance in Bangladesh: Challenges and Prospects", Intellectual Discourse, Vol. 26, No. 2, pp. 1129-1165.

15. Islamic Development Bank (2018), Islamic Solidarity Fund for Development, Ihsan Waqf Investment Funds, With Banks and Financial Institutions, [Online] available from:

https://isfd.isdb.org/EN/ProjectsAndPrograms/Documents/4\%20Pages\%20Ihsan\% 20Waqf\%202018\%20English\%20New\%20Logo.pdf [Accessed on 20 July 2019].

16. Jabatan Wakaf, Zakat dan Haji (2006), Manual Pengurusan Tanah Wakaf (Manual for Management of Waqf Land), Putrajaya : Jabatan Wakaf, Zakat dan Haji.

17. Khan N.A. and Jareen S. (2015), "The Waqf and Human Security in Muslim Majority Countries: Traditions, Modern Practices, and Challenges", In: Hasan S. (Eds) Human Security and Philanthropy: Nonprofit and Civil Society Studies. New York: Springer. https://doi.org/10.1007/978-1-4939-2525-4_7

18. Lahsasna, A. and Hassan, K. M. and Ahmad, R. (2018), Forward Lease Sukuk in Islamic Capital Markets, Switzerland: Palgrave Macmillan. https://doi.org/10.1007/978-3-319-94262-9

19. Maierbrugger, A. (2017), "Philippines planning Islamic finance scheme to rebuild southern city", Gulf Times, [Online] available from: https://www.gulftimes.com/story/557077/Philippines-planning-Islamic-finance-scheme-to-reb [Accessed on 20 July 2019].

20. Maierbrugger, A. (2019), "Philippines seeks Islamic funding to develop halal industry in Mindanao", Gulf Times, [Online] available from: https://www.gulftimes.com/story/619296/Philippines-seeks-Islamic-funding-to-develop-halal [Accessed on 20 July 2019].

21. Malaysia International Financial Centre (MIFC) (2013), Innovation for Growth Bael III Creates A Golden Opportunity, [Online] available from: http://www.mifc.com/index.php?ch=28\&pg=72\&ac=49\&bb=uploadpdf [Accessed on 20 July 2019].

International Journal of Management and Applied Research, 2019, Vol. 6, No. 2 
22. Mohsin, M. and Muneeza, A. (2019), "Integrating Waqf Crowdfunding into the Blockchain: A Modern Approach for Creating a Waqf Market", in: Oseni, U. A and Ali, S. N. (Ed.), Fintech in Islamic Finance Theory and Practice, London: Routledge, pp. 266-280.

23. Muneeza, A.; Arshad, N. A. and Arifin, A. T. (2018), "The Application of Blockchain Technology in Crowdfunding: Towards Financial Inclusion via Technology", International Journal of Management and Applied Research, Vol. 5, No. 2, pp. 82-98. https://doi.org/10.18646/2056.52.18-007

24. Nagaoka, S. (2016), "Revitalization of Waqf in Singapore: Regional Path Dependency of The New Horizons in Islamic Economics", Kyoto Bulletin of Islamic Area Studies, Vol. 9, No. 1, pp. 4-18.

25. Niforos, M.; Ramachandran, V.; Rehermann, T. (2017), Block Chain: Opportunities for Private Enterprises in Emerging Market. Washington, D.C.: International Finance Corporation, available from: https://openknowledge.worldbank.org/handle/10986/28962 [accessed on 1 Aug 2018].

26. Rafay, A., Sadiq, R. and Ajmal, M. (2017), "Uniform framework for Sukuk alIjarah - a proposed model for all madhahib", Journal of Islamic Accounting and Business Research, Vol. 8 No. 4, pp. 420-454. https://doi.org/10.1108/JIABR-092015-0042

27. Regencia, T. (2019), "A failure: Marawi verdict on Duterte ahead of annual address", $A l$ Jazeera [Online] available from: https://www.aljazeera.com/news/2019/07/failure-marawi-verdict-duterte-annualaddress-190722010958139.html [Accessed on 20 July 2019].

28. Reuters (2012), MIDEAST DEBT-Sukuk become tool in Basel III capital-raising, [Online] available from: https://www.reuters.com/article/islamic-finance-hybridsidUSL5E8LGUAQ20121122 [Accessed on 20 July 2019].

29. Sadeq, A. (2002), "Waqf, perpetual charity and poverty alleviation", International Journal of Social Economics, Vol. 29 No. 1/2, pp. 135-151. https://doi.org/10.1108/03068290210413038

30. Suroyo, G. (2018), "Indonesia launches cash endowments-linked sovereign Islamic bonds", Reuters [Online] available from: https://www.reuters.com/article/imf-worldbank-islamicfunds/indonesia-launchescash-endowments-linked-sovereign-islamic-bonds-idUSL2N1WU033 [Accessed on 20 July 2019]. 